\title{
HISTORY AND CULTURE IN LANGUAGE EDUCATION: MONUMENTS AND MEMORIALS AS EXPRESSIONS OF COLLECTIVE MEMORY
}

\author{
HANNA KOMOROWSKA
}

\section{Introduction}

Sociocultural aspects, as an integral element of a broader programme aiming at the integration of intercultural and linguistic competences, form an indispensable component of second and foreign language education today (Badstübner-Kizik and Hille, 2015; Byram, 2008; Dervin and Risager, 2015). Thought-provoking topics contribute to the development of the motivational self-system of the learner (Dörnyei, 2009), while the introduction of the cultural content into language curricula correlates with higher educational achievement, a result demonstrated in the research on 50000 European school learners (European Union, 2012). Valuable information related to history, geography and culture can also play an important role in encouraging critical thinking and nuanced approaches to complex social issues. Monuments, memorials and museums proliferating in the world present a great opportunity here as they combine past, present and future through their natural association with the culture of memory and collective identity.

Today historians and anthropologists warn their readers that as mass culture tempts us to celebrate living in the present, we need to remember how strongly its image depends on the past and how history shapes our identity and memory. Warnings have a useful preventive function, but in this sphere they do not seem to be immediately necessary. Monuments and commemorations are mushrooming literally everywhere. Why? Alvarez offers an answer stating that "this phenomenon, which is 
recognizable on a global scale, responds to deeper structural causes than strictly political ones. Between them lies the desire and necessity to protect personal and collective identity against the global transformations taking place at present, which suffocate, transform and destroy some of the traditional bases of that identity" (Alvarez, 2009: 405). That is what anchors memorials and monuments in the past and guarantees their importance for the community. Julian Bonder points out that 'The construction of memorials and museums and the ever-increasing growth of memorial acts across the globe is significant in their sheer number, as well as the significance they hold for affected communities. Examples include the creation of official and community-based memorials and museums, the emergence of spontaneous memorials in places of recent tragedy, pilgrimages to sites of memory, and other commemorative practices' (Bonder, 2009: 62). Analyses of this kind often focus on the relation of memorials to the history of the nation, yet monuments are designed and erected not only to commemorate past events, but also to shape attitudes and influence future behaviour.

Although memorials are naturally linked to aspects of the concept of time, personal and collective identity is also shaped by space, which offers room for expression of group values - issues discussed not only by historians, but also by philosophers (Eliade, 1959; Heidegger, 1927/2008; Merleau-Ponty, 1945; Ricoeur, 2006), semiologists (Lotman, 1977) and humanistic geographers (Soja, 1989; Tuan, 1977).

Monuments, memorials and commemorations of various kinds integrate meanings and emotions evoked by both of these factors, which makes them a stimulating topic of class discussion. To plan and conduct the educational activity in this field, a broader understanding of their role and function is needed.

The present text will, therefore, seek to analyse the roles of time and space in shaping collective memory as well as their impact on planning and erecting monuments and memorials in order to identify messages they are meant to communicate, functions ascribed to them, but also forms selected to ensure efficient transmission of intentions and fates they meet when social and political intentions change.

\section{What to commemorate? Collective memory, collective identity}

History as cultural memory (Kansteiner, 2002) is always emotionally loaded. Positively charged memories produce restorative nostalgia which recreates former memories, but also reflective nostalgy in which memories, critically analysed, undergo constant valorisation (Boym, 2001; Megill, 1998).

The well-known mediaevalist, Johannes Fried, stresses that cultural memory is shaped, distorted and petrified not only by reminding, but also by forgetting (Fried, 2014). Suppression plays an important role in what a given society considers itself to 
be (Leder, 2014; Winter, 1995), but conscious avoidance of certain topics also carries important information (Bateson, 1972; Watzlawick et al., 1967).

Yet, as Christian Meier (2014) points out, forgetting is not necessarily bad. It can also function as a new strategy in the process of dealing with controversy. Historically, abolition meant forgetting all aspects of the conflict-generating past to reset the scene. The famous Ciceronian appeal after the assassination of Julius Caesar showed the completeness of abolition as did Charles the Bald's equally powerful "nothing will be kept in our memory" promised at Angers after the battle of Jengland or the Indemnity and Oblivion Act of the English Parliament in 1660 (Connerton, 2008; Meier, 2014).

What underlies the need for monuments and memorials is the culture of memory, a concept used since the introduction of the notion of layers of collective memory (Halbwachs, 1925/1992). The construct was later used to analyse cultural memory through art as demonstrated in Aby Warburg's (1866-1929) unfinished Mnemosyne Atlas and has been employed till today both in research on historical memory (Whitling, 2010) and in designing monuments reflecting it. Their erection and their form depend on the current interpretation of history. Bonder reminds that 'though the culture of memory has spread around the globe and the political uses of memory are varied, at its core the use and abuse of memory remain tied to official histories of specific communities, nations, and states' (Bonder, 2009: 62).

Symbolic interpretations of history differ in and across time. An important role in this valorisation is played by politics. Maurice Halbwachs contends that there are as many memories as there are groups; politics is about which group has a voice in which time and context and uses it in shaping, retaining, but also manipulating history (Halbwachs, 1925/1992). Messages circling in each community are, therefore, by no means uniform or congruent. Different ways of remembering Jeanne d'Arc are a powerful example here: in the leftist memory she was betrayed by the Church and the King, in the rightest opinion she was a God-sent hero (François and Schulze, 2014). Individual memory is thus bombarded by conflicting collective memories; the result is internally negotiated and may in turn cause changes in the collective memory which also undergoes valorisation.

Collective memory is selective as we interpret the past on the basis of our experience within social and cultural frameworks in which we live. It is also prone to manipulation, especially when the past is put at the service of the present to achieve immediate goals, a tendency referred to as presentism (Olick and Robbins, 1998). Unfortunately, historical truth is not always the best group-forming strategy; manipulation often proves much more effective. "Getting its history wrong is crucial for the creation of a nation," said Ernest Renan in his 1882 address to French nationalists (quoted after Osborne, 2001: 8). Anyway, history is important in shaping the cultural memory of social groups (Kansteiner, 2002; Megill, 1998; Olick et al., 2011) and thus influences what a given group wants to commemorate in order to 
transmit their image of the community to future generations and to populate their public memory (Assmann, 2001).

But how do societies retain memory of the past?

Connerton distinguishes two ways of remembering used in commemoration: remembrance-based inscription and behaviour-based incorporation. Monuments and inscriptions have always been privileged - a phenomenon Connerton called cognitive imperialism (Connerton, 1989), their shape and role being determined not only by the type of event they commemorate, but also by the type of space for which they have been designed.

More and more often not only sites of historical events are selected, but also empty spaces: squares in new residential districts, roundabouts, closed-down industrial plants or railway stations, places formerly devoid of meaning are now designated to create new associations while new senses are ascribed to them. The functions of space in general and the duality of commemorative spaces in particular seem worth examining.

\section{Where to commemorate? Space in preserving and reconstructing collective memory}

Space, as the main foundation of our psychological integrity, is important for the development of both individual and collective memory (Augé, 1992, 1998; Morley, 2000; Porębski, 2002; Puppel, 2009).

In the space of the home country a significant role is played by places which saw events or people important for a given community. Those places are commemorated in a variety of ways including monuments, plaques, inscriptions or abstract forms of commemoration.

Commemorations occupy three types of public spaces lieux - emplacements, contre-lieux -counter-emplacements and non-lieux - non-places.

In our everyday life our perspective on space narrows down to lieux - emplacements. Foucault (1967/2008) saw emplacements as heterotopic spaces viewed in binary oppositions, (e.g. public/private) either horizontally (sacred / profane places) or vertically (this world/the other world). Monuments and commemorations usually occupy spaces considered sacred, public or cultural.

Emplacements can be just lieux, but also lieux de mémoire - sites of memory. In Pierre Nora's original definition lieux de mémoire are not necessarily material and may include more than just places (Nora, 1989). Their physical features are not important; what makes them important is past history and the will to remember (Olsen, 2003). In fact any form of the presence of history in our lives can be included in the long list of lieux de mémoire, but especially memorials as they have a symbolic meaning and a memory-oriented dimension. 
Places functioning as lieux de mémoire are not selected accidentally. Geography of memory 'locates history and its representations in space and landscape. It answers the question where is memory in terms of places and sites that cast a certain vision of history into a mold of commemorative permanence' (Foote and Azaryahu, 2007: 127). Categories of what tends to be commemorated include battle scenes, war episodes, birthplaces of heroes, saints or historical figures; sanctuaries and religious centers, but also territories that played a key role in the founding of a given state.

Sometimes the main idea is to maintain the sacred nature of a certain lieu de mémoire, such as a temple, a cemetery or place of a past graveyard. Sometimes the intention is for the commemoration to serve the sacralisation of a certain space which saw important or tragic events of the past - lieu then becomes lieu de mémoire. Both enable what Marianne Hirsch calls post-memory, indirect memory or mediated memory, sending messages to those who were not in any direct contact with people or events being commemorated (Hirsch, 2012). Commemoration in this context bridges a so-called floating gap (Niethammer, 2014; Vansina, 1985) between the generation who keeps certain facts in their autobiographical memory and the generation who cannot remember them. To use Assmann's terminology, young generations can no longer rely on communicative memory and have to depend on cultural memory instead (Assmann, 1995, 2008), which also means that they have to face the situation whereby their politically controversial questions are considered illconstructed, springing from different assumptions, ideologies or criteria (Hölscher, 2014). This has recently been reflected in a controversy which started in March 2015 over the Cecil Rhodes statue at the Oxford Oriel College. A large group of students wanted the statue to be taken down, citing what they believe is its celebration of the imperialist legacy, while the college stated the statue of the College's most generous benefactor would not be removed as the context of Rhodes' activity was different in his times. A financial aspect was also at play as donors started to cancel donations and alumni threatened to rewrite their wills.

Most, though by no means all, of the monuments located at lieux de mémoire communicate traditional values, commemorate past events and tend to petrify already formed images of the past.

In external space we also deal with contre-lieux - counter-emplacements mentally located half way between real places (topos) and imagination oriented places (ou-topos), historically used for rites of passage, today functioning as heterotopias, e.g. cinemas and theatres, or as heterochronies including cemeteries, museums and libraries (Foucault, 1967/2008). These might house monuments as elements of their space, e.g. statues to honour religious figures (Puppel, 2014) or sculptures to commemorate individuals whose life and activities had been connected with that particular space, such as Nicolas Stone's statue of Sir Thomas Bodley in the courtyard of Oxford's Bodleian Library. This statue has never been contested, thanks to the as yet uncontroversial activity of the Library's founder. 
Now our concept of space has changed under the influence of cultures on the road, pilgrimages, tourism, professional and educational mobility (Clifford, 1997) thus opening new spaces for public communication. Movement and speed accompanied by the search for safety and economic stability produced a new type of emplacement - the so-called non-lieux or non-places (Augé, 1992) - transient spaces with no history: motorways, hotel chains, supermarkets, public squares, etc., places which eliminate subjectivity and individuality, designed for temporary stay (Benko, 1997), sometimes perceived as nowherevilles / no-where-villes / now-here-villes (Garreau, 1992). People who find themselves there form what Bauman calls cloakroom communities, temporary groupings tied by space, such as concert-rooms or events, such as theatrical performances, with no shared group interest (Bauman, 1997).

With the multiplicity of non-places, monuments, memorials and public art obtain a new location and a new channel for message transmission, especially since non-places are general, anonymous, dynamic, ephemeral, anarchic, while places tend to be concrete, named, static, stable and orderly. Paul Celan first noticed the phenomenon of non-places in his poem Embankments, Waysides, Vacant Lots, Rubble (Celan, 1959/1973), but it was Augé who introduced the concept to anthropology and sociology (Augé, 1992). Although non-places are often perceived negatively, they can become a useful concept in the debate on museums, art installations and monuments, a category of our special interest here. Non-places, calling to be filled in, are often used nowadays to exhibit new forms of art, often carrying meanings intended to change attitudes and undermine stereotypes.

Discussing sociolinguistic scales Blommaert argues that spaces are meaningful in relation to other spaces, that they are stratified and layered and adds that focusing on space as an agentive force entails issues of scale. Vertical moves between scales open access to particular symbolic resources and involve the interplay of power (Blommaert, 2005, 2007, 2010). This statement can easily be applied to relations between physical spaces and symbolic spaces of commemorations - no wonder Dani Karavan selected a location opposite Berlin's Reichstag for his Sinti and Roma Memorial - an impressive black pool, a lake-like commemoration of the Nazis' Romani victims, a work of art we will look at in more detail in the following section.

\section{How to commemorate? Monuments and counter-monuments}

There are four material media of memory: rites, narratives, representations and objects located in selected places - monuments and other forms of commemoration are a significant subgroup here (Olsen, 2003, 2013).

Traditional monuments and memorials typically appeal to restorative nostalgy and petrify existing perspectives on events, but certain points in time give rise to 
a general tendency to change the older generation's attitudes and points of view as well as enable the younger one to distance itself from the deeds of their parents and grandparents. Sometimes this change is accepted, but sometimes attitudes are rigid and minds are not open to change. Monuments are then planned by those who want to face the challenge. New, unexpected forms of commemoration are looked for, forms that aim to introduce an element of surprise, elicit astonishment and combine reflective and didactic functions, possibly operating on the viewer's subconscious. As artists enthusiastically respond to the call, the element of the unexpected becomes a more and more common attention-getter for fear an installation would go unnoticed and fail to fulfil its functions.

This trend is powerfully illustrated by a move, conspicuous in Germany at the turn of the 1980s and the 1990s, to construct what are often called countermonuments (Young, 1992), such as the Aschrott Brunnen. The fountain, originally funded by a Jewish citizen in Kassel, was destroyed by the Nazis and replicated in 1985 by Horst Hoheisel in the form of a sunken fountain, turned upside down and dug deep into the earth. The artist himself, quoted in James E. Young's essay, described the concept as follows: 'I have designed the new fountain as a mirror image of the old one, sunk beneath the old place in order to rescue the history of this place as a wound and as an open question, to penetrate the consciousness of the Kassel citizens so that such things never happen again. That's why I rebuilt the fountain sculpture as a hollow concrete form after the old plans and for a few weeks displayed it as a resurrected shape at City Hall Square before sinking it, mirror-like, 12 meters deep into the ground water' (Young, 1992).

Rachel Whiteread's Holocaust Memorial in Vienna's Judenplatz is another example of a counter-monument - rows of modules with casts of twenty books each, every volume inaccessible, 'positioned with its spine turned inward, each nearly identical in height and thickness' (Comay, 2002: 252).

An even more impressive counter-monument - Micha Ullman's Bibliothek - can be found beneath Berlin's Bebelplatz. A hollow pit sealed with glass with walls covered in empty bookshelves was placed in the middle of the square at the site of Nazi book-burning (Jordan, 2006: 123).

Both counter-monuments, as Huyssen puts it, were erected to counteract what he called 'the cultural amnesia' and were designed in opposition to figurative monuments celebrating and legitimizing nation-states (Bonder, 2009; Huyssen, 1994). Young suggests that postwar Germans in particular shared 'distrust of monumental forms in light of their systematic exploitation by the Nazis' (Young, 1994: 27). A similar attitude might be expected of citizens of the countries exposed to vast numbers of realistic commemorations of people and events they never identified with in the communist era, yet, this does not seem to be the case. Most of the recently erected monuments support the opinions of sociologists who point out that pluralization of history often creates an empty space immediately being filled out by mass 
culture (Levy and Sznaider, 2014) or at least by 'culture for the masses'. This unavoidably brings realistic forms back, though with a different message.

There are, however, other trends, mainly related to the popularity of conceptual and critical art among young artists in Europe. The following examples from Poland and Germany can serve to illustrate this phenomenon.

Joanna Rajkowska's Greetings from Jerusalem Avenue, an art installation in the form of a surreal palm tree mounted in Warsaw Aleje Jerozolimskie in 2002, recalls history and etymology of the street's name, refers to the Jewish population of pre-war Warsaw and, as the artist herself states, 'challenges its invisibility' (www.rajkowska.com). The form of the memorial is in line with Dali's famous statement "Objects were found to have the magic power of uncovering our subconsciousness, provoking visions and dreams - they gained a symbolic function becoming objects surrealists, exotic, disquieting, ready to appeal to the unconscious" (Dali, 1931).

An extraordinary concept with an element of surprise also makes Esther ShalevGerz and Jochen Gerz's Monument Against Fascism unforgettable. A 12-metre memorial column with an invitation for passers-by to engrave their names on it was erected in 1986 in Harburg-Hamburg. It was divided into horizontal sections to the lowest of which passers-by added their signatures. When the space was filled, that section of the column was lowered into the earth to offer a clean section to be covered with names. When the whole column was filled with names, it would completely disappear so that, from that moment on, everybody would be responsible for guarding the memory of the victims. Some 70000 names after its unveiling, the column sank below the surface in 1993. Its authors hope for "a further shift in perspective in terms of how memory can become a mechanism for social change..." (Synenko, 2014).

Minority groups often find ways to gain visibility through art. Alison Landsberg's statement seems particularly valid here: "Mass culture has had the unexpected effect of making group-specific cultural memories available to a diverse and varied populace. In other words, this new form of memory does not, like many forms of memory that preceded it, simply reinforce a particular group's identity by sharing memories. Instead, it opens up those memories and identities to persons from radically different backgrounds" (Landsberg, 2004: 10-11).

Unorthodox artistic solutions are usually more effective in attracting passers-by attention in public spaces. Dani Karavan's Sinti and Romani Memorial mentioned in the section above - a stone stele in the shape of a concentration camp triangle, bearing a flower, rises to the surface of the round, black pool, to the sound of a violin tune; when the flower withers, the stele disappears beneath the surface, and the cycle begins again - is a powerful illustration of this tendency.

The power of attention-getters is also exemplified by a multicolour Rainbow designed by Julita Wójcik in 2012. A three-year installation made of artificial flowers, 
located in Warsaw's Saviour Square, was repeatedly burnt and reinstalled, aggressively attacked by opponents and carefully protected by supporters of the LGBT movement.

Minorities choose modern forms of monuments, memorials and art installations, but at the same time modern forms attract minorities: most of the feminist and leftist parades in Warsaw start from the meeting point under a surreal palm tree from Rajkowska's Greetings from Jerusalem Avenue. The influence is, therefore, bidirectional.

Commemoration in conceptual art, even if not explicitly visible, can carry impressive messages. Horst Hoheisel authored one of the projects offered when the competition for the Berlin Jewish memorial was thrown open and suggested exposing important German symbols to similar horrors which happened to the Jews, e.g. he advised to demolish the Brandenburg Gate, grind it and cover its ashes with street tarmac (Young, 2000). The fact that the Federal Government would never agree to having this done, i.e. the obvious official refusal on the part of the establishment, was considered an integral part of the project. Because of its dramatic character, the project - which by definition was doomed to rejection - ensured a much wider promotion of the author's sensitization activity than any realistic plan could ever enjoy.

\section{How stable is commemoration? Dynamism of collective memory and fates of monuments}

As Alvarez puts it, "geographers have investigated in the past years the influence of social memory on the transformation of landscape with regard to nationalistic criteria, the erection of emblems, monuments and rituals for nationalistic purpose; the materialization of a nationalistic iconography in the landscape... . The recent geographical studies have shown that both the spatial dimensions of public memory are dynamic and that, over time, some commemorative elements are added while others disappear, at the same time that the same monuments can be reinterpreted and their significance disputed and transformed" (Alvarez, 2009: 408).

Central and Eastern Europe offer many examples of additions, modifications and disappearances, e.g. Hungarian statues of the Habsburgs were removed from the Millennium Memorial in Budapest Heroes' Square (Hösök Tere) after World War II and replaced by statues of freedom fighters approved by the Stalinist government. In the same era the statue of Kossuth commemorating the 1848 uprising was considered too pessimistic for the communist promoters of the then strictly required 'voluntary enthusiasm', a typical example of Batesonian double bind (Bateson, 1972), and had to be replaced by a new one with Kossuth full of energy in the pose of an orator (Janowski, 2016).

Powerful multiple messages are transmitted when commemorations themselves are being commemorated as exemplified by the history of The Monument of Grun- 
wald Victory in Cracow. Funded by Ignacy Paderewski, designed and made by Antoni Wiwulski, unveiled on the 500th anniversary of the success in the battle with Teutonic knights, it was torn down by German soldiers in 1939 and later commemorated not only in the form of its copy in Cracow, but also on the Grunwald battlefield to which some stone blocks - residues of the original monument - were transported after the war. The return of the blocks demonstrates the persistence and stubbornness of efforts to commemorate the Polish-Lithuanian victory.

An even more complex situation can be seen when multiple messages in public spaces change their content and direction several times.

Consider, for example, the content changes introduced by the German government to modify meanings ascribed to the Tannenberg Denkmal. The memorial was created to commemorate the Prussian victory over the Russian army in 1914, then extended to commemorate Prussian soldiers fallen during the Great War and finally changed into an impressive Hindenburg Mausoleum, a place of national pilgrimages, officially opened by Adolf Hitler in 1935. Directions of messages changed when the Mausoleum, partially destroyed at the end of the World War II by the retreating German soldiers and its remnants blown up by the Red Army, for some time remained a ruin confirming the fall of the Third Reich, as skilfully depicted in Dorota Nieznalska's exhibition The Past that Does not Intend to Pass (Nieznalska, 2015). In the Stalinist era, the debris became a rich source of building blocks used to construct parts of the Palace of Culture in Warsaw, of the Central Committee of the Communist Party (later turned into the seat of the stock exchange and real estate offices), but also to create a monument to the Red Army in the city of Olsztyn. This monument in the form of an incomplete archway was designed by Xawery Dunikowski, one of the best Polish sculptors, and was then secretly perceived by the population as carrying a veiled double message: commemorating the Russian victory, but - hidden in the incompleteness of the triumphal arch - also predicting the future fall of the communist regime. This hidden message is now being overlooked by Poland's ruling party and the the local community; the monument, recently vandalised, is scheduled for destruction as no more than a relic of the communist era.

As the examples above demonstrate, both content and types of messages differ considerably, reflecting the fact that memory is a process of recalling and reconstructing the past to construct contemporary points of view. Spaces and events formerly forgotten or ignored by the government tend to be placed centre-stage as illustrated by the new glory of Polish partisans forming the post-war anti-communist opposition. On the other hand, events, people or denominations that were once officially celebrated, are no longer deemed worthy of such attention. The history of the Alexander Nevski Cathedral in Warsaw serves as one of the many examples here. The Russian Orthodox temple funded by the tsarist administration to become the tallest building in Poland's capital city in 1912 was completely destroyed after Po- 
land regained its independence six years later. In 1926 no trace of it could be seen on the main Plac Saski (Saxon Square) where it had been erected.

Many more examples of anger directed at buildings or monuments which were in consequence destroyed can be cited, e.g. the huge Stalin monument erected in 1951 in Budapest met the same fate during the Hungarian uprising of 1956 and so did the Warsaw statue of Feliks Dzierżyński (Dzerzhinsky), chief of the Soviet secret police - the Cheka. The fate of monuments erected on the Polish territory in the communist era is a powerful illustration of tendencies to dispute and transform messages, though not necessarily the realistic forms of monuments, a phenomenon noticed also in other countries of the former Soviet bloc (Pasewalck, 2015).

\section{What is the effect on the viewer? Factors underlying the power of memorials and monuments as commemoration messages}

There are several reasons for the power of memorials and monuments as commemoration messages in public spaces.

Firstly, they are objects / things, a feature strongly stressed since material culture has regained its status in cultural anthropology. The word "thing" is etymologically based on its cumulative function "to put together" and on its relation to time: "tinku" means extended time, duration (Olsen, 2013), perhaps because as Fried stresses, time changes into places (Fried, 2014).

Secondly, they are "embodied" - social relations are objectified, reified and presented in them and through them. For that reason they become what Walter Benjamin called our embodied traces (Benjamin, 1935/1970).

Thirdly, the group of objects including monuments and commemorations, on the force of the very fact that they make a powerful combination of verbal and spatialvisual information, can produce a sense of shock which as Walter Benjamin believed "like all shocks, should be cushioned by heightened presence of mind" (Benjamin, 1969: 17). The power of vision is especially impressive when time is conflated with space, forming what Bakhtin calls chronotopes (Bakhtin, 1981).

And last but not least - as Löfgren points out - we are not IN the world; like flâneurs or tourists we gaze AT the world (Löfgren, 2014), which adds to the force of monuments we encounter on our way.

Especially in the times of media bombarding us with stimuli, monuments and commemorations offer a certain degree of visual and emotional stability, even if this stability is based not on their presence, but on their absence resulting from military action. Emptiness and void speak even more dramatically if the absence is painful, because symbols glorifying the past are torn down and desired commemorations are forbidden. As soon as the political situation permits it, relocated monuments are 
restored to their former places and destroyed ones are carefully reproduced, if symbols are still valued.

The examples above raise the question of the emotions elicited by monuments. Out of six basic emotions (Ekman, 1999; Izard, 2007) - i.e. anger, joy, surprise, fear, sadness and disgust - sadness is obviously the emotion most often intended by the artists, given the many tragic events commemorated. Davies contends that unlike real-life situations, where what makes us sad brings about negative consequences, sadness elicited by a work of art is safe (Davies, 2001).

Realistic, figurative monuments achieve an intended emotional effect according to resemblance of the work of art to a given situation as the contour theory proposes (Davies, 2001) or - as Robinson's (2005) expression theory suggests - by presenting an actor who lives through certain emotional processes. These processes are recognized by the viewer through messages transmitted by gestures and body posture (Puppel, 2014). This is possible because the model becomes reified, which enables symbolic reinterpretation; as symbols operate within epistemological schemas, interpretations cannot be easily reduced to subjective impressions (Juszczak, 2010). Abstract art work can also elicit an emotional response in another way, i.e. by producing what Norman calls a visceral effect which might then lead to a cognitive reaction of the recipient (Norman, 2004). Both approaches to design provide sensory stimuli that bring the past back to us or encourage new associations. This explains why memorials, monuments and commemorations can be equally effective taking so varied forms.

A work of art's effect on the viewer is usually assessed according to a theory based on criteria described as goodness, power and activity (Schröder et al., 2011). The three dimensions are presented either as PAD: $\mathrm{P}$ - pleasure, $\mathrm{A}$ - arousal and $\mathrm{D}$ dominance (Mehrabian, 1996) or as EPA: E - evaluation on the pleasant - unpleasant scale related to approach or avoidance, $\mathrm{P}$ - potency evaluated on the strength and weakness scale related to action and refraining from action and $\mathrm{A}$ - activity evaluated on a relaxation and tension scale related to physiological, facial and nonverbal components (Fontaine et al., 2007). Realistic memorials tend to build on pleasure, dominance and relaxation, while abstract ones lean towards action and tension extremes of the scale.

The combination of space and emotion strengthens the effect on the viewer, a phenomenon often referred to in ethnographic reflection which, as Yael NavaroYashin puts it, merges theories of affect and subjectivity with those of language and materiality (Navaro-Yashin, 2009).

Meanings ascribed to material aspects of spaces, landscapes and emplacements can be intensified, reshaped or imposed in a variety of ways. Erecting monuments and planning commemorations is only one of those ways. The human tendency to take part in rituals, ceremonies and mass processions has long been known. In today's world, increasing sensitivity to spatial / visual aspects inspires artists to come 
up with new forms of theatricalization, reconstruction and performance (Szpociński, 2008). Their function, is however, similar. As Osborne puts it, "such commemorative ceremonies constitute a theatre of memory whose performances remind a community of its identity through a master narrative that engenders the sense of a collective autobiography" (Osborne, 2001: 25). These forms of commemoration do not reduce attention given to traditional monuments and memorials; on the contrary, artistic activities often start or end in their locations.

Artistic activity related to monuments can also take the form of a sociopolitical campaign. For example, Ilona Németh and Jonathan Ravasz prepare a record of monuments of Hungarian heroes on the present Slovak territory. They produce picture postcards showing them, exhibit printed postcards in international galleries, give them away for free and encourage the viewers to participate in the consciousness-raising campaign which the artists describe as follows, 'Over the last twenty years, erecting figures of Hungarian national heroes in the public squares of Slovakian towns that used to be part of Austria-Hungary has become a peculiar form of practicing local historical politics. Please, take one postcard. You can send the memorial back to where it came from - or anywhere else' (Németh and Ravasz, 2013/2016).

\section{Conclusion. Implications for teachers and teaching}

Monuments and commemorations have the potential to carry both cognitive and affective messages as well as to play both reflective and didactic functions. That is why the process of commemoration is strongly influenced and often straightforwardly steered by the policy of memory, heavily dependent on current political tendencies. Evaluations are difficult and change with time (Connerton, 2008; Besier, 2014), being always subjective and emotionally loaded. Memorials, therefore, lend themselves to being used as springboards for discussions, debates and role-plays related to history as they often commemorate destruction, but at the same time they elicit hope that it will not be repeated, and that it paves the way to new, more optimistic developments - in line with Walter Benjamin's idea of Progress rising from a pile of debris as depicted in his allegory of the angel of history inspired by Paul Klee's 'Angelus Novus' (Benjamin, 1970). That is why monuments and memorials ignite discussions focusing on current events, controversial issues and scenarios for future action, which can be incorporated in the educational process across the school curriculum in the teaching of history, geography, civic education, but also languages, especially - though not only - when students come from different cultural backgrounds

It can be argued that discussions of this kind call for at least intermediate language advancement. Obviously, the richer the language, the richer the debate, espe- 
cially when discussion partners have strong beliefs, knowledge and arguments. Yet even at lower levels of language proficiency, thanks to the abundance of visual stimuli, uncomplicated descriptions as well as one-word associations elicited by monuments and memorials can be presented and these can be communicated in simple language. The ambiguity of counter-monuments elicits a sufficient variety of perceived images, interpretations and reactions to accommodate linguistic needs and possibilities of mixed ability groups.

Elements of drama can also be employed in school's educational activity considering the role of reconstruction and performance in contemporary societies. Trivial information on typical festivals and celebrations repeatedly presented in foreign language teaching materials can be replaced by less commonly discussed forms of commemorative ceremonies that can give a multisided picture of the target language community and its subgroups with often conflicting beliefs and opinions.

Such a cross-curricular approach contributes to the promotion of content and language integrated learning (CLIL), and encourages divergent and critical thinking as well as problem-solving. It also helps to develop a student's intercultural competence, opening a path for comparisons of one's own culture with that of the target language community. What is more, it invites new technologies through data search and webquests which can be used in the course of in- and out-of-school project work. The resulting collaboration of teachers will certainly add to the quality of whole school education.

\section{Bibliography}

Alvarez, J.G. 2009. "Places, landscapes and policies of memory: a geographic lecture'. Boletín de la A.G.E. 51. 405-409.

Assmann, A. 2001. "History and memory". In: Smelser, N.J. and B. Baltes (eds). International encyclopaedia of the social and behavioural sciences. Amsterdam: Elsevier. 6822-6823.

Assmann, J. and J. Czaplicka. 1995. "Collective memory and cultural identity". New German Critique 65, Cultural History/Cultural Studies. 125-133.

Assmann, J. 2008. "Communicative and cultural memory". In: Erll, A. and A. Nünning (eds.). Cultural memory studies. an international and interdisciplinary handbook. Berlin/New York: Mouton de Gruyter. 109-118.

Augé, M. 1992. Non-lieux. Introduction à une anthropoligie de la surmodernité. Paris: Seuil.

Augé, M. 1998. The sense of the other. Stanford: Stanford University Press. 108-109.

Badstübner-Kizik, C. and A. Hille (eds). 2015. Kulturelles Gedåchtnis und Erinnerungsorte im Hochschuldidaktischen Kontext. Frankfurt am Mein: Peter Lang.

Bakhtin, M. 1981. "Four essays by M.M. Bakhtin". In: Holquist, M. (ed.). The dialogic imagination. Austin: University of Texas Press.

Bateson, G. 1972. Steps to an ecology of mind. San Francisco: Chandler.

Bauman, Z. 2000. Globalizacja. Warszawa: Państwowy Instytut Wydawniczy. 40-42.

Benjamin, W. 1935/1969. "The work of art in the age of mechanical reproduction". In: Benjamin, W. Illuminations. New York: Schocken Books. 217-252.

Benjamin, W. 1935/1970. "Theses on the philosophy of history". In: Benjamin, W. Illuminations. London: Cape. 245-255. 
Benko, G. 1997. "Introduction: modernity, postmodernity and social sciences”. In: Benko, G. and $\mathrm{U}$. Strohmayer (eds). Space and social theory. Interpreting modernity and postmodernity. Malden/Oxford: Wiley-Blackwell. 1-44.

Besier, G. 2014. Neither good nor bad. Why human beings behave how they do. Newcastle upon Tyne: Cambridge Scholars Publishing.

Blommaert, J. 2005. Discourse: a critical introduction. Cambridge: Cambridge University Press.

Blommaert, J. 2007. "Sociolinguistic scales". Intercultural Pragmatics 4.1. 1-19.

Blommaert, J. 2010. The sociolinguistics of globalization. Cambridge: Cambridge University Press.

Bonder, J. 2009. "On memory, trauma, public space, monuments, and memorials". Places 21.1. 62-69. http://escholarship.org/uc/item/4g8812kv

Boym, S. 2001. The future of nostalgia. New York: Basic Books.

Byram, M. 2008. From foreign language education to education for intercultural citizenship. Clevedon: Multilingual Matters.

Celan, P. 1959/1973. "Embankments, waysides, vacant lots, rubble". In: Cameron, B.A. Anticomputer: an essay on the work of Paul Celan followed by selected poems in translation. Berkeley: University of California. PhD Dissertation.

Clifford, F. 1997. Routes. Travel and translation in the late twentieth century. Harvard: Harvard University Press.

Comay, R. 2002. "Memory block: Rachel Whiteread's Holocaust Memorial in Vienna". In : Hornstein, S. nad F. Jacobowitz (eds.). Image and remembrance: representation and the Holocaust. Bloomington: Indiana University Press.

Connerton, P. 1989. How societies remember. Cambridge: Cambridge University Press.

Connerton, P. 2008. "Seven types of forgetting". Memory Studies 1. 59-71. DOI: 10.1177/ 1750698007083889

Dali, S. 1931. Object surrealiste. Paris: SADLER.

Davies, S. 2001. "Philosophical perspectives on music's expressiveness". In: Juslin, P.N. and J.A. Sloboda (eds). Music and emotion: theory and research. Oxford: Oxford University Press. 23-44.

Dervin, F. and K. Risager (eds). 2015. Researching identity and interculturality. London: Routledge.

Dörnyei, Z. 2009. “The L2 motivational self system”. In: Dörnyei, Z. and E. Ushioda (eds). Motivation, language identity and the L2 self. Clevedon: Multilingual Matters. 1-43.

Ekman, P. 1999. "Basic emotions". In: Dalgleish, T. and M.J. Power (eds.). Handbook of cognition and emotion. New York: John Wiley and Sons. 45-60.

Eliade, M. 1959. The sacred and the profane. The nature of religion. New York: Harcourt, Brace and World.

European Union. 2012. Surveylang - First European Survey on Language Competences. Final Report. Brussels: EU Publishing.

Foote, K. and M. Azaryahu. 2007. "Toward a geography of memory. Geographical dimensions of public memory and commemoration". Journal of Political and Military Sociology 35. $125-144$.

Foucault, M. 1967/2008. "Of other spaces". In: Dehaene, M. and L. De Cauter (eds.). Heterotopia and the city. Public space in a postcivil society. London: Routledge. 13-30.

François, É. and H. Schulze. 2014. "Niemieckie miejsca pamięci - wprowadzenie [2001]". In: Kończal, K. (ed.). (Kon)teksty pamięci. Kraków: Narodowe Centrum Kultury. 173-189.

Fried, J. 2014. „Zasłona pamięci. Ogólny zarys memoryki historycznej - cztery przypadki [2004]”. In: Kończal, K. (ed.). (Kon)teksty pamięci. Kraków: Narodowe Centrum Kultury. 279-326.

Garreau, J. 1992. Edge city. Life on the new frontier. New York: Anchor Books.

Halbwachs, M. 1925/1992. On collective memory. Chicago: The University of Chicago Press.

Hirsch, M. 2012. The generation of postmemory. New York: Columbia University Press.

Huyssen, A. 1994. Twilight memories: marking time in a culture of amnesia. London: Routledge. 
Hölscher, L. 2014. „Pamiętać czy zapomnieć. O prawidłowym obchodzeniu się z narodowosocjalistyczną przeszłością. Dziesięć lat później [1999]”. In: Kończal, K. (ed.). (Kon)teksty pamięci. Kraków: Narodowe Centrum Kultury. 85-97 .

Izard, C.E. 2007. „Basic emotions, natural kinds, emotional schemas and a new paradigm”. Perspectives on Psychological Science 2-3. 260-280.

Janowski, M. 2016. "Najpiękniejsza stolica prowincjonalna [The most beautiful provincial capital]". Ale Historia 18.07.2016. 3-5.

Jordan, J. 2006. Structures of memory: understanding urban change in Berlin and beyond. Palo Alto: Stanford University Press.

Juszczak, W. 2010. Wędrówka do źródet [Going to the sources]. Gdańsk: Słowo/Obraz/Terytoria.

Kansteiner, W. 2002. "Finding meaning in memory: a methodological critique of collective memory studies". History and Theory 41. 179-197.

Landsberg, A. 2004. Prosthetic memory. The transformation of American remembering in the age of mass culture. New York/Chichester: Columbia University Press.

Leder, A. 2014. Prześniona rewolucja. Ćwiczenia z logiki historycznej [Dreamt revolution. Exercises in historical logic]. Warszawa: Wydawnictwo Krytyka Polityczna.

Levy, D. and N. Sznaider. 2014. "Holokaust jako polityka historyczna [2001]”. In: Kończal, K. (ed.). (Kon)teksty pamięci. Kraków: Narodowe Centrum Kultury. 161-171.

Lotman, J. 1977. In: Janus, E. and M.R. Mayenowa (eds.). Semiotyka kultury [Semiotics of culture]. Warszawa: Państwowy Instytut Wydawniczy.

Löfgren, O. 2014. "Urban atmospheres as brandscapes and lived experience". Place Branding and Public Diplomacy 10.4. 255-266.

Megill, A. 1998. "History, memory, identity". History of the Human Sciences 11.3. 37-62.

Mehrabian, A. 1996. "Pleasure-arousal-dominance: a general framework for describing and measuring individual differences in temperament". Current Psychology 14.4. 261-292.

Meier, Ch. 2014. "Pamiętanie - wypieranie - zapominanie [2001]". In: Kończal, K. (ed.). (Kon)teksty pamięci. Kraków: Narodowe Centrum Kultury. 141-158.

Merleau-Ponty, M. 1945. La phénoménologie de la perception. Paris: Gallimard.

Morley, D. 2000. Home territories. Media, mobility, identity. London: Routledge,

Navaro-Yashin, N. 2009. "Affective spaces, melancholic objects: ruination and the production of anthropological knowledge". Journal of the Royal Anthropological Institute (N.S.) 15. 1-18.

Németh, I. and J. Ravasz. 2013/2016. Retour. Artwork presented at an exhibition entitled "Travellers. Voyage and Migration in New Art from Central and Eastern Europe". Warsaw: Zachęta National Gallery of Art, 14.05.2016 - 21.08.2016.

Niethammer, L. 2014. „Po tej stronie floating gap. Pamięć zbiorowa i konstrukcja tożsamości w dyskursie naukowym [1995]". In: Kończal, K. (ed.). (Kon)teksty pamięci. Kraków: Narodowe Centrum Kultury. 31-51.

Nieznalska, D. 2015. The past that does not intend to pass. Exhibition in the PGS Gallery in Sopot.

Nora, P. 1989. "Between memory and history - les lieux de mémoire". Representations 26 (Special Issue: Memory and Counter-Memory). 7-24.

Olick, J.K. and J. Robbins. 1998. "Social memory studies: from 'collective memory' to the historical sociology of mnemonic practices". Annual Review of Sociology 24. 105-140.

Olick, J., Vinitzky-Seroussi, V. and D. Levy (eds.). 2011. The collective memory reader. Oxford: Oxford University Press. 300-303.

Olsen, B. 2003. "Material culture after text: re-membering things". Norwegian Archaelogical Review 36.2. 87-104.

Olsen, B. 2013. W obronie rzeczy. Archeologia i ontologia przedmiotów [In Defence of things. Archaeology and ontology of objects]. Warszawa: Instytut Badań Literackich.

Osborne, B.S. 2001. "Landscapes, memory, monuments, and commemoration: putting identity in its place". Paper Commissioned by the Department of Canadian Heritage for the Ethnocultural, Racial, Religious, and Linguistic Diversity and Identity Seminar. Halifax, Nova Scotia. Available on-line in English and French at www.metropolis.net [accessed 04.05.2016]. 
Passewalck, S. 2015. "Erinnerungsorte im Fremdsprachenunterricht als Arena". In: BadstübnerKizik, C. and A. Hille (eds). Kulturelles Gedåchtnis und Erinnerungsorte im Hochschuldidaktischen Kontext. Frankfurt am Mein: Peter Lang. 167-183.

Porębski, M. 2002. Polskość jako sytuacja. Kraków: Wydawnictwo Literackie.

Rajkowska, J. 2002. Greetings from Jerusalem Avenue. An installation in Warsaw. www.rajkowska.com.

Puppel, S. 2009. „Uwagi w sprawie konieczności ochrony dziedzictwa kulturowo-językowego, czyli od ojcowizny i ojczyzny do wspólnoty światowej”. Acta Pomerania 2. 101-108.

Puppel, J. 2014. Obecność i rola gestów rytualnych w przestrzeni publicznej. Analiza rzeźb sakralnych $w$ światyniach katolickich na terenie miasta Poznania $i$ wybranych okolic. Poznań: Wydawnictwo Naukowe UAM.

Ricoeur, P. 2006. History, memory, forgetting. Chicago: The University of Chicago Press.

Robinson, J. 2005. Deeper than reason: emotion and its role in literature, music and art. Oxford: Oxford University Press.

Schröder, T., Netzel, J., Schermuly, C.C. and W. Scholl. 2013. "Culture-constrained affective consistency of interpersonal behavior. A test of affect control theory with nonverbal expressions”. Social Psychology 44.1. 47-58.

Soja, E.W. 1989. Postmodern geographies: the reassertion of space in critical social theory. New York: Verso.

Synenko, J. 2014. "The remainders of memory: Berlin's postnational aesthetic". Drain 11.2. http://drainmag.com [accessed 24 July 2016].

Szpociński, A. 2008. "Miejsca pamięci (lieux de mémoire)". Teksty Drugie 4. 11-20.

Tuan, Y.-F. 1977. Space and place. The perspective of experience. Minneapolis: University of Minnesota Press.

Vansina, J. 1985. Oral tradition as history. Madison: University of Wisconsin Press.

Watzlawick, P., Bavelas, J.B. and D.D. Jackson. 1967. Pragmatics of human communication. New York: Norton.

Whitling, F. 2010. "Damnatio memoriae and the power of remembrance". In: Pakier, M. and Bo Stråth (eds.). A European memory? Contested histories and politics of remembrance. New York/Oxford: Berghahn Books.

Winter, J. 1995. Sites of memory, sites of mourning. The Great War in European culture and history. Cambridge: Cambridge University Press.

Young, J.E. 1992. "The counter-monument: memory against itself in Germany today". Critical Inquiry 18. 267-296.

Young, J.E. 1994. The texture of memory: Holocaust memorials and meaning. New Haven: Yale University Press. 43.

Young, J.E. 2000. At memory's edge: after images of the Holocaust in contemporary art and architecture. New Haven: Yale University Press. 92-93. 
